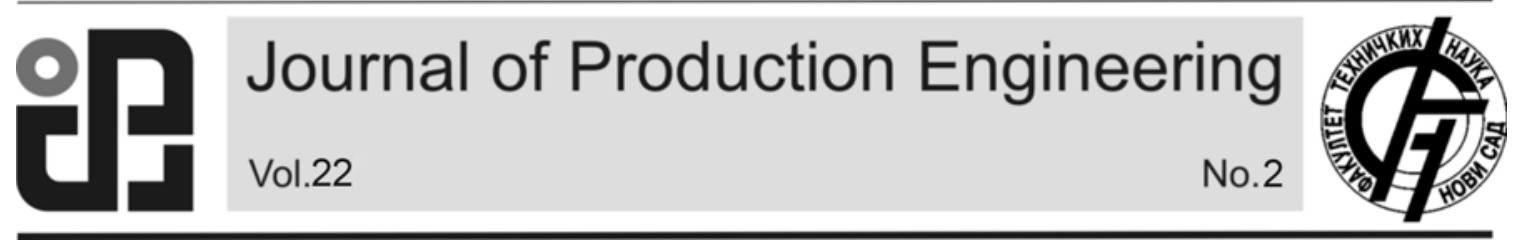

JPE (2019) Vol.22 (2)

Babic, M., Kovac, P., Savkovic, B.

Original Scientific Paper

\title{
USING GENETIC PROGRAMMING TO MODEL PROCESS OF ROBOT LASER HARDENING
}

Received: 11 July 2019 / Accepted: 29 September 2019

\begin{abstract}
This article describes the fractal geometry of robot laser hardening microstructure at different parameter. We show the experimental results and analysis of fractal patterns that occur in robot laser hardening at different parameter. In the end we present fractal geometry in point robot laser hardening pattern. Robotic laser hardening is used in the aerospace, automotive and military industries. Fractals can be defined in many ways, the simplest definition being that they do not change shape with scale, and thus they exhibit self-similar properties. Their fundamental property is fractal dimension D, which yields important insights into the physical properties of geological objects. Fractals are a beautiful of mathematics and art. Perhaps this is the reason why most people recognize fractals only as pretty pictures useful as backgrounds on the computer screen or original postcard patterns. The fractal patterns look complex in robot laser hardened patterns to. Fractal structures can be find in robot laser hardened patterns to if it was observed it with electron microscope. Robot laser surface hardening heat treatment is complementary to the conventional flame or inductive hardening. In this work we have used scanning electronic microscope (SEM), search and analyze the fractal structure of the robot laser-hardened material. It was use method of intelligent system, namely genetic programming to model hardness in depth of robot laser hardening. Key words: Robot, laser, hardening, genetic programming.
\end{abstract}

Korištenje genetskog programiranja za modeliranje procesa očvršćavanja dobijenog uz pomoć robotskog lasera. Ovaj članak opisuje fraktalnu geometriju mikrostrukture očvrsnuća laserom pomoću robota pri različitim parametrima. Prikazani su eksperimentalni rezultati $i$ analiza fraktalnih obrazaca koji se pojavljuju pri laserskom kaljenju pomoću robota na različitim parametrima. Na kraju je prikazana fraktalna geometriju u uzorku laserskog kaljenja pomoću robota. Robotsko lasersko očvršćivanje koristi se u vazduhoplovnoj, automobilskoj $i$ vojnoj industriji. Fraktali se mogu definisati na više načina, najjednostavnija definicija je da ne menjaju oblik sa skalom, $i$ na taj način pokazuju slična svojstva. Njihovo osnovno svojstvo je fraktalna dimenzija D, koja daje važan uvid u fizička svojstva geoloških objekata. Fraktali su prelepa matematika i umetnost. Možda je to razlog što većina ljudi prepoznaje fraktale samo kao lepe slike korisne kao pozadine na ekranu računara ili originalne obrasce razglednica. Fraktalni obrasci izgledaju složeno u uzorcima očvrsnutih pomoću laserskog robota. Fraktalne strukture možemo pronaći u uzorcima laserski očvršćenih na robotima, ako bi se posmatrali na elektronskom mikroskopu. Termička obrada površinskog otvrdnjavanja pomoću laserskog robota komplementarna je uobičajenom plamenu ili induktivnom kaljenju. U ovom radu korišćen je skenirajući elektronski mikroskop (SEM), pretraženi $i$ analizirani su fraktalna struktura materijala koji je očvršćen laserom. Korišćen je metod inteligentnog sistema, odnosno genetsko programiranje za modeliranje tvrdoće u dubini sloja laserski očvrsnutog pomocu robota. Ključne reči: Robot, laser, kaljenje, genetsko programiranje.

\section{INTRODUCTION}

Laser hardening [1] is a metal surface treatment process complementary to conventional aime and induction hardening processes. A high-power laser beam is used to heat a metal surface rapidly and selectively to produce hardened case depths of up to $1,5 \mathrm{~mm}$ with the hardness of the martensite microstructure providing improved properties such as wear resistance and increased strength. Fractal patterns are observed in computational mechanics of elastic-plastic transitions. The Fractal dimension is a property of the fractal, which is maintained through all the extensions and is therefore well denned. In addition, it shows how complex the fractal is. The Fractal dimension is generally not calculated by the above-mentioned procedure, as this is possible only on pure mathematical constructs, which do not exist in nature.
Fractal [2] is a letter made by Benua Mandelbrot for this purpose combine under one heading an extensive class of objects played the historical role in the development of pure mathematics. At the risk of answering the call, I thought and worked out the new geometry of Nature, and also found for its application in many diverse fields. The new geometry is capable describe many of the irregular and fragmented forms in the world around us and give birth to completely completed theories, identifying the family of figures that I call fractals. From the moment of the book B. Mandelbrot's "Fractal Geometry of Nature" began the burgeoning development of fractal geometry. Fractals found practically everyone natural phenomena and processes. Fractal models applied in medicine for early diagnosis of cancerous tumors; in material studies in the study of the processes of destruction of products; in nuclear physics and astronomy for the study of 
elementary particles, the distribution of galaxies in the universe, the processes of the sun; in computer science for data compression and traffic enhancement on the Internet; for analysis volatility of market prices in economics, heart rate in cardiology, weather in meteorology...

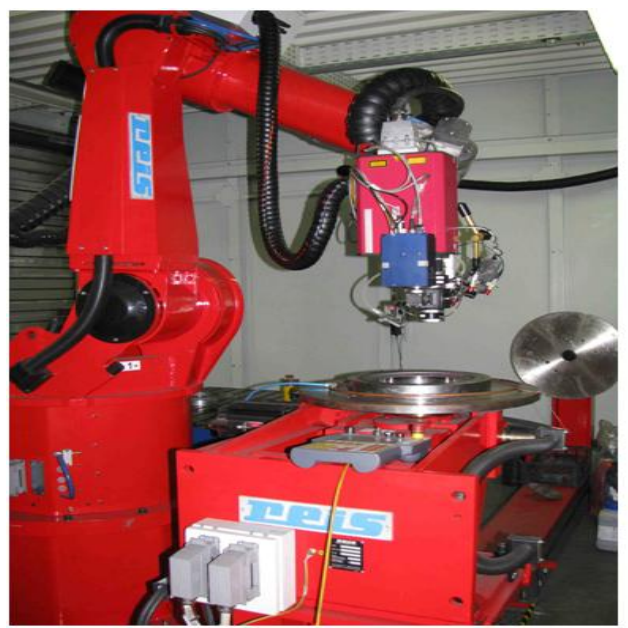

Fig. 1. Robot laser cell

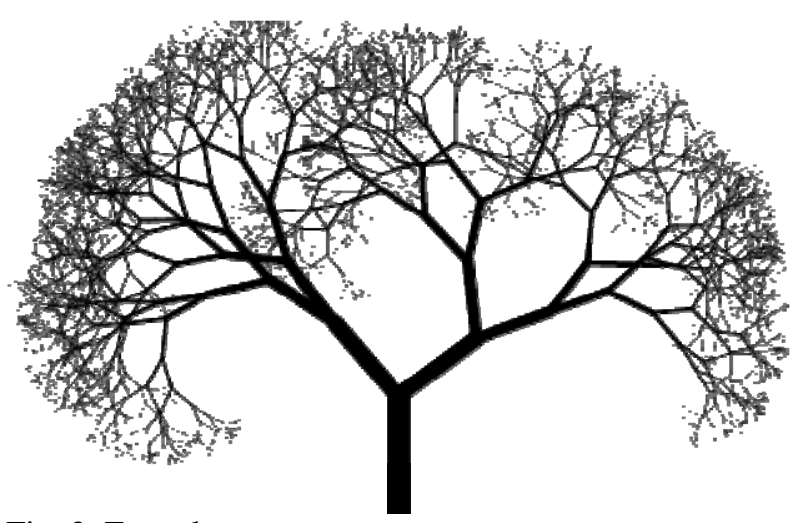

Fig. 2. Fractal

Machine learning [3] is a method of data analysis that automates analytical model building. It is a branch of artificial intelligence based on the idea that systems can learn from data, identify patterns and make decisions with minimal human intervention.

Evolutionary calculations [4], synonymous with prices in foreign countries literature is the term "evolutionary computation", proved its effectiveness as in the solution of artificial intellect (face recognition, clustering, associative search), and in solving the laborious tasks of optimization, approximation, intellectual data processing. Genetic Programming is inspired by biological evolution. It is a machine learning technique used to optimize a solution based on a fitness score. Genetic programming may be more powerful than neural networks and other machine learning techniques that are able to solve problems in a wider range of disciplines. The general idea behind genetic programming is: to start with a collection of functions and combine them randomly into programs; then run the programs and see which gives the best results; keep the best ones (natural selection), mutate some of the others, and test the new generation; repeat this process until a clear best program emerges.

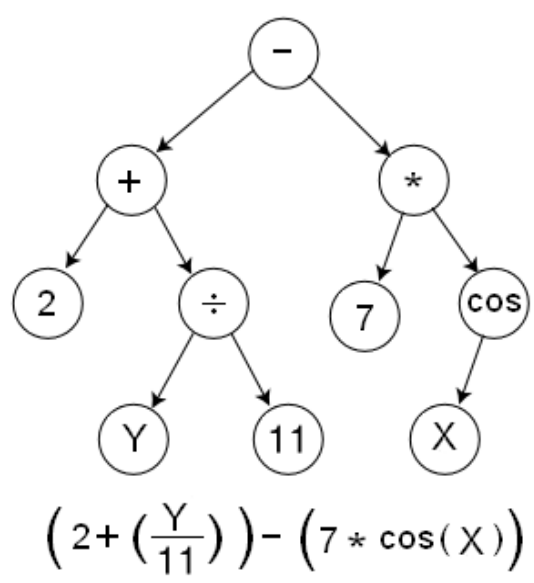

Fig. 3. Genetic programming model

\section{MATERIALS PREPARATION AND METHODS}

Our study was limited on tool steel standard label of DIN standard 1.7225 (Fig. 1). The chemical composition of the material contained 0.38 to $0.45 \%$ C, 0.4\% maximum Si, 0.6-0.9\% Mn, 0.025\% maximum P, $0.035 \%$ maximum S and $0.15-0.3 \%$ Mo. The specimen test section had a cylindrical form dimension $25 \times 10 \mathrm{~mm}$ (diameter $\times$ high). Speciment with the porosity about $19 \%$ to $50 \%$, were prepared by laser technique, followed by hardening at $\mathrm{T} \in[1000,1400]{ }^{\circ} \mathrm{C}$ and $\mathrm{v} \in$ $[2,5] \mathrm{mm} / \mathrm{s}$.

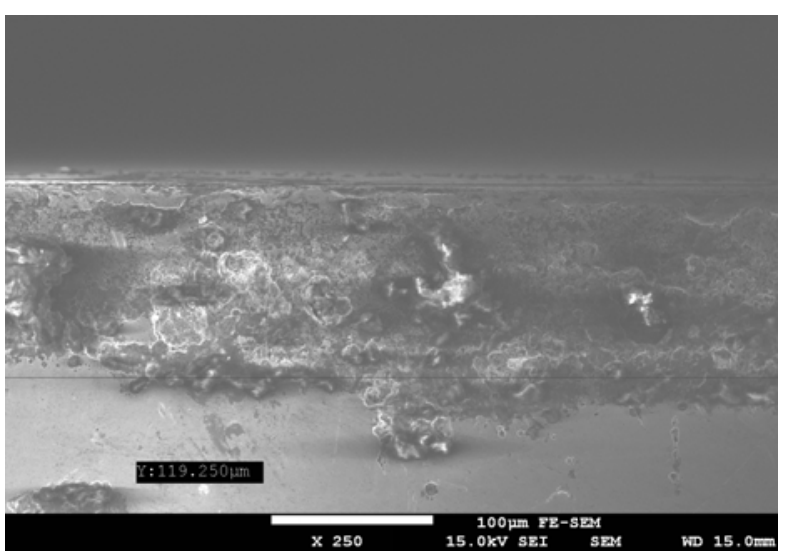

Fig. 4. Robot laser hardened specimens - hardened cone

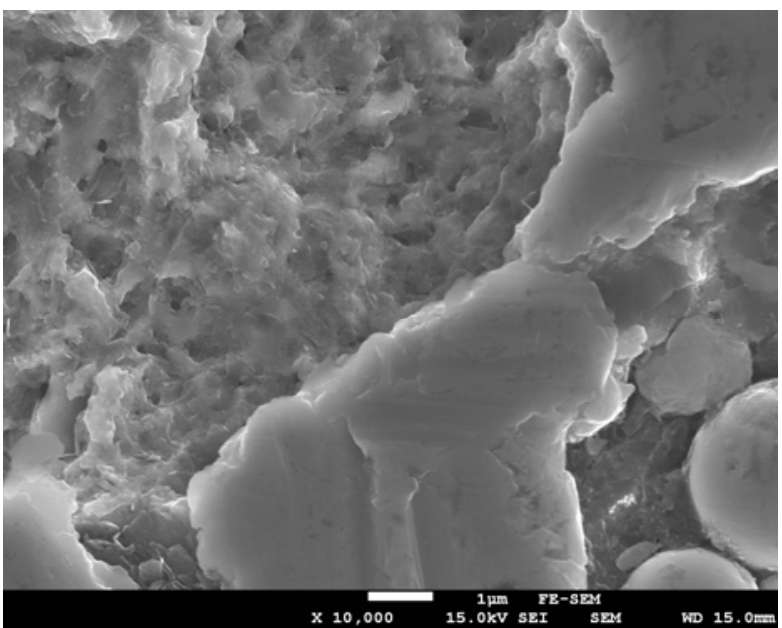

Fig. 5. Microstructure of robot laser hardened specimen 
We used an intelligent system method; genetic programming for modelling hardness in depth of robot laser hardened specimens.

\section{RESULTS AND DISCUSSION}

In Table 1, the parameters of the hardened specimens impacting the hardness in depth of robot laser hardened specimens are presented. The specimens from P1 to P21 are marked. Parameter $\mathrm{x}_{1}$ represents the temperature in degrees Celsius [C], $\mathrm{x}_{2}$ represents the speed of hardening $[\mathrm{mm} / \mathrm{s}], \mathrm{x}_{3}$ represents fractal dimension in 2D and $\mathrm{Y}$ represents hardness in depth of robot laser hardened specimens. Figure 6 represent hardness in depth of robot laser hardened specimen. Fig. 7 represent genetic programming model.

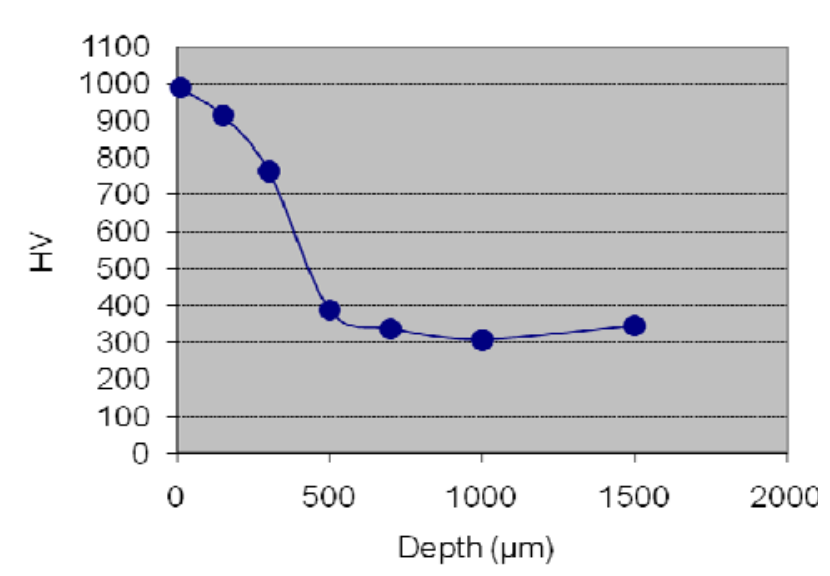

Fig. 6. Hardness (HV) in depth of robot laser hardened specimen

$$
\begin{aligned}
& Y=\frac{X 1}{X 4}+\frac{X 1}{-11.7+\frac{-5.356+X 4}{X 5}+0.17 \times X 1 \times X 6}-X 5+(-5.356-X 4+X 6) \\
& 6 \times X 4+\frac{X 1}{-11.7+\frac{-5.356+X 4}{X 5}+0.17 \times X 1 \times X 6}+X 6-\frac{X 1 \times X 1 \times X 5}{X 4 \times\left(2 \times X 6+\frac{5.356 \times X 1}{2 \times X 4+2 \times X 6}\right)}+\frac{(X 2-1.9381) \times X 2}{X 3-0.1768} \\
& (-5.356-X 4) \times X 5-\frac{X 1}{X 4+X 6}-\frac{X 1}{-7.513 \times X 4 \times(-5.356-X 4)+\frac{X 4 \times(X 6-X 5)}{X 5}-\frac{X 1 \times X 1 \times X 5}{X 4 \times(-X 4+2 \times X 6)}}
\end{aligned}
$$

Fig. 7. Model of genetic programming

\begin{tabular}{lllll}
\hline $\mathrm{S}$ & $\mathrm{X}_{1}$ & $\mathrm{X}_{2}$ & $\mathrm{X}_{3}$ & $\mathrm{Y}$ \\
\hline $\mathrm{P} 1$ & 1000,0 & 2,0 & 1,9135 & 60 \\
\hline P2 & 1000,0 & 3,0 & 1,9595 & 58,7 \\
\hline P3 & 1000,0 & 4,0 & 1,9474 & 56 \\
\hline P4 & 1000,0 & 5,0 & 1,9384 & 56,5 \\
\hline P5 & 1400,0 & 2,0 & 1,9225 & 58 \\
\hline P6 & 1400,0 & 3,0 & 1,9784 & 57,8 \\
\hline P7 & 1400,0 & 4,0 & 1,9540 & 58,1 \\
\hline P8 & 1400,0 & 5,0 & 1,9776 & 58,2 \\
\hline P9 & 1000,0 & 2,0 & 1,9720 & 57,4 \\
\hline P10 & 1000,0 & 3,0 & 1,8580 & 56,1 \\
\hline P11 & 1000,0 & 4,0 & 1,9784 & 53,8 \\
\hline P12 & 1000,0 & 5,0 & 1,9410 & 56 \\
\hline P13 & 1400,0 & 2,0 & 1,9784 & 55,3 \\
\hline P14 & 1400,0 & 3,0 & 1,5810 & 57,2 \\
\hline P15 & 1400,0 & 4,0 & 1,9650 & 57,8 \\
\hline P16 & 1400,0 & 5,0 & 1,8113 & 58 \\
\hline P17 & 800,0 & 0,0 & 1,9669 & 52 \\
\hline P18 & 1400,0 & 0,0 & 1,9753 & 57 \\
\hline P19 & 2000,0 & 0,0 & 1,9706 & 56 \\
\hline P20 & 950,0 & 0,0 & 1,9631 & 58 \\
\hline P21 & 850,0 & 0,0 & 1,9537 & 57 \\
\hline 1able & Parame & \\
\hline
\end{tabular}

Table 1. Parameters and hardness (HRc) of hardened specimens
Table 2 presents experimental and prediction data regarding the hardness in depth of robot laser hardened specimens. In Table 2, the symbol $\mathrm{S}$ represents the name of the specimens, E experimental data and GP prediction with genetic programming, Figure 8.

The hardness structure of a material is an important mechanical property that affects the hardness of materials. Here we use fractal geometry to describe the hardness of robot laser-hardened specimens. In this paper, we describe how the parameters (speed and temperature) of the robot laser cell affect hardness metal materials using a new method, for calculating fractal dimension in 3D space.The fractal analysis of a series of digitized surface microstructures from the robot laser surface modified specimens indicated that useful correlations can be derived between the fractal dimensions and the surface microstructural features such as hardness.

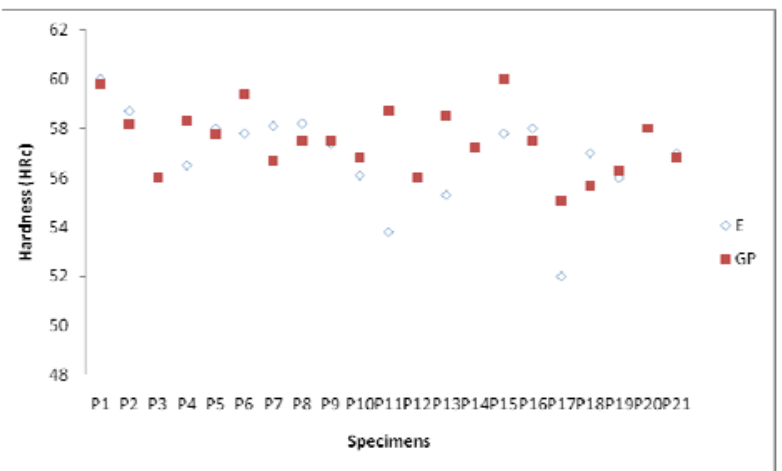

Fig. 8. The measured and predicted volume of robot laser hardened specimens 


\begin{tabular}{lll}
\hline S & E & GP \\
\hline P1 & 60 & 59,8 \\
\hline P2 & 58,7 & 58,2 \\
\hline P3 & 56 & 56,0 \\
\hline P4 & 56,5 & 58,3 \\
\hline P5 & 58 & 57,8 \\
\hline P6 & 57,8 & 59,4 \\
\hline P7 & 58,1 & 56,7 \\
\hline P8 & 58,2 & 57,5 \\
\hline P9 & 57,4 & 57,5 \\
\hline P10 & 56,1 & 56,8 \\
\hline P11 & 53,8 & 58,7 \\
\hline P12 & 56 & 56,0 \\
\hline P13 & 55,3 & 58,5 \\
\hline P14 & 57,2 & 57,2 \\
\hline P15 & 57,8 & 60,0 \\
\hline P16 & 58 & 57,5 \\
\hline P17 & 52 & 55,1 \\
\hline P18 & 57 & 55,7 \\
\hline P19 & 56 & 56,3 \\
\hline P20 & 58 & 58,0 \\
\hline P21 & 57 & 56,8 \\
\hline Tabe
\end{tabular}

Table 2. Experimental and prediction data

\section{CONCLUSION}

The paper present using of genetic programming to predict hardness of depth of robot laser hardened specimens. With fractal geometry we describe the complexity of robot laser hardened specimens. The hardening of various metal alloys has shown that when melting occurs, fractal geometry can be used to calculate the fractal dimension. In the future, we want to explore new method for calculating fractal dimension in 3D space as a function of the parameters of a robot cell for laser hardening for pinned robot laser hardening: laser parameters such as power, energy density, focal distance, energy density in the focus, focal position, the shape of the laser flash, flash frequency, temperature and speed of hardening.

\section{REFERENCES}

[1] J. Grum, P. Žerovnik, R. Šturm: Measurement and Analysis of Residual Stresses after Laser Hardening and Laser Surface Melt Hardening on Flat Specimens; Proceedings of the Conference "Quenching '96", Ohio, Cleveland, 1996.

[2] Falconer, Kenneth (2003). Fractal Geometry: Mathematical Foundations and Applications. John Wiley \& Sons. xxv. ISBN 978-0-470-84862-3.

[3] Zhang, Jun; Zhan, Zhi-hui; Lin, Ying; Chen, Ni; Gong, Yue-jiao; Zhong, Jing-hui; Chung, Henry S.H.; Li, Yun; Shi, Yu-hui (2011). "Evolutionary Computation Meets Machine Learning: A Survey". Computational Intelligence Magazine. 6 (4): 6875. doi:10.1109/mci.2011.942584.

[4] Spector, Lee; Robinson, Alan (2002-03-01). "Genetic Programming and Autoconstructive Evolution with the Push Programming Language". Genetic Programming and Evolvable Machines. 3 (1): 7-40.

Authors: ${ }^{1}$ Assist. Prof. Dr. Matej Babič, ${ }^{2}$ Professor Pavel Kovac PhD, ${ }^{2}$ Assist. Professor Borislav Savkovic PhD,

${ }^{1}$ Faculty of Information studies, Novo mesto, Slovenia, ${ }^{2}$ University of Novi Sad, Faculty of Technical Sciences, Institute for Production Engineering, Trg Dositeja Obradovica 6, 21000 Novi Sad, Serbia, Phone.: +381 21 450-366, Fax: +381 21 454-495.

E-mail: babicster@gmail.com pkovac@uns.ac.rs savkovic@uns.ac.rs 